\title{
Pedagogy of Creative Drama in Biology
}

\author{
Arzu Saka1, Jazlin Ebenezer², Ilknur Çakır'1, Ahmet Zeki Saka1 \\ ${ }^{1}$ Fatih Faculty of Education, Karadeniz Technical University, Trabzon, Turkey \\ ${ }^{2}$ Curriculum and Instruction Programme, Collage of Education, Wayne State University, Detroit, USA \\ Email: arzus123@gmail.com
}

Received 24 February 2016; accepted 21 March 2016; published 24 March 2016

Copyright (C) 2016 by authors and Scientific Research Publishing Inc.

This work is licensed under the Creative Commons Attribution International License (CC BY).

http://creativecommons.org/licenses/by/4.0/

(c) (i) Open Access

\section{Abstract}

Creative drama grants students not only an opportunity to display their thoughts physically, orally and written but also enables them to interpret the expressions of peers. Characteristic of learning through creative drama is the development of shared meaning through the social construction of knowledge. The primary purpose of this study is to develop seventh-grade students' conceptual understanding of some genetic concepts, attitudes toward biology learning and awareness of forensic science. The pedagogy of creative drama consisted of determining blood types and differences in human fingerprints. Twenty students took part in this study. Data sources consisted of student journaling, classroom observations, students' responses to attitude survey and subject evaluation forms. Students learned that within the scope of creative drama activities, how the blood group determination and the cause of people's fingerprints were separate from each other. In everyday life, they realized how important biology is, especially in criminal work. Changes in students' attitudes toward biology indicated a positive direction because of the extraordinary teaching method. All of the participants contribute the creative drama activity keenly. Students' attitudes toward the pedagogy of creative drama suggest that students should be approached with this sort of learning at an early age.

\section{Keywords}

\section{Biology Education, Creative Drama}

\section{Introduction}

Creative drama is an idea, concept or event that uses theater techniques or play-like processes [1]. Creative drama creates a learning environment that enables students to access new knowledge and skills based on their prior experiences. Students often actively participate in courses that integrate drama. Students also construct their knowledge with the help of their teacher [2]-[4]. Creative drama activities can help to form new con- 
nections using a child's background knowledge [5]. So it could be one of the constructivist approach's practice. Besides students express their thoughts verbally, written and physically. Concurrently, they can understand and interpret the forms of other students' self-expressions. A shared meaning develops as they encounter objects and events within a social environment. The learning characteristics of drama seem to have an appeal to most learners. Integration of dramas into education provides an alternative approach to learning [6] [7]. Although drama may also be seen as an art form, with its unique conventions, languages and methods of expression.

The learning process in drama is dynamic in three respects: physically, consciously, and interpersonally. In the traditional ways of learning, for example sitting, listening, and copying, the drama process requires commonly body movement. With the drama teacher's guidance, children "explore, develop, express and communicate ideas, concepts and feelings through dramatic enactment" [8]. Secondly, the learning in drama is consciously dynamic. Because when students play a role, they come in and out between real and imagined world of drama. This situation provides them to reflect their role's critically. Students hold the two forms in mind at the same time, this situation is referred by Augusto Boal as "metaxis" [9]. Students perform themselves playfulness also have well concentrated. They may also gain insight and viewpoint. In addition to the approaches, the learning context of drama also contributes to the nourishment of possibility thinking [10]. It allows thirdly, drama itself is an interactive process in which social creativity [11] is nurtured. Children commonly need to collaborate with their peers for drama activities. These activities are very important and potentially offers the pathways to empathy building [12].

Some basic values are required in creative drama activities to reach learners of all level ages: Creative drama increases imagination, promotes independent thinking, allows cooperative learning and creates social sensibility [13]. Children not only live through their knowledge by acting in a different role, but also learn to pose questions, find out more possibilities, take risks, and be playful in inventing new ideas. For learning through drama a teacher ought to guide students to conduct an open communication with each other, provide them comfortable and flexible classroom environment so that they may creatively express their thoughts [4]. School teachers and drama practitioners employ an inclusive and hybrid approach and integrate various educational drama models, conventions, activities and elements into their classrooms and call them "drama pedagogy". This new pedagogy is widely portrayed as a playful, creative, activity-based and student-centred teaching method in the education reform documents [14] [15]. The permanence of knowledge taught at school increases by connecting students to daily life [16]. One of the most effective ways to bring students' awareness of daily life is to use applications of creative drama [2] [16]-[19].

\section{Problem Statement}

Creative drama are used in science education [20]. These authors concluded that creative drama contributes to students' understanding of the nature of science. Drama are recognised as effective tools for engaging children with science [21] and drama has been completely used to improve a personal dimension to social and scientific issues [22] [23]. This personal dimension is extremely important in the generation of science knowledge. One of the topics of science is genetic. Genetic concepts are increasingly taking a more visible role in our lives [24]. For instance, traits and health of a child can be controlled before birth. Because of genetics research rapid progress have been made in cancer research, autoimmunology, organ transplantation, genetic engineering, tissue regeneration and in vitro fertilization. It is hard to think of a society whose members are not informed about these developments. Basic knowledge is necessary in order to appreciate the news and research about genetics from the popular media, such as TV, radio, newspaper and magazines [25] [26]. It is also a necessity for students who may take part in ethical, social and educational decisions. Despite its importance, genetics is generally not effectively taught because both teachers and students regard it as a difficult subject [24] [27]-[34]. Teachers ought to connect genetics to daily life [24].

This study is significant for several reasons:

-Although local researchers focus on the effectiveness of "drama in education" in teacher development or curriculum change. However, there is a lack of concern about the actual practice of "drama in education" in the classroom and also there is little research on its practical effectiveness.

-Unlike most studies, this interventional study uses creative drama to probe into the effect on students' attitudes toward biology learning, conceptual understanding and the awareness of some genetic issues.

-No study has been reported focusing on the classroom instruction of the concept of blood type and finger- 
printing, although there are some studies that investigate students' conceptions of the DNA-gene-chromosome, including the genetic [30]-[32] [35]-[37]. Students of all age groups should be provided a strong background in genetics particularly at the molecular level [38]. Direct explanation and traditional teaching approaches do not suffice to help students understand abstract concepts in genetics [39]-[41]. Therefore, it is extremely important to expose students to genetic concepts through defensible approaches to learning. Hence, this study provides an extraordinary science activity through defensible approach.

Finally, this study combines the science topics and creative drama activity. The aim of this study is to enhance seventh-grade elementary school students' understanding of the importance of blood type and fingerprinting processes through creative drama activities in education. The activity selected for this study is called, "You are Unique in the World!”. Another purpose is to improve students' attitudes toward learning biology by connecting genetics to issues in daily life.

Based on these objectives, two research questions are framed:

1) Does the creative drama activity significantly improve seventh-grade students' conceptual understanding and awareness in terms of some genetic concepts?

2) Does the creative drama activity increase seventh-grade students' attitudes toward biology learning?

\section{Method}

The group teaching drama technique was used. This technique comprises two components; "creative drama" and "pedagogic drama". Creative drama is more commonly used in teaching and learning. Creative drama is characteristic of constructivist learning approaches because it includes activities that recreate events, facts, experiences and knowledge [21] [42]. The creative drama experiences consist of several stages, which are referred to as the preparation-warm up stage, enactment stage, and evaluation-discussion-sharing stage [13]. In addition to the previous stages, improvisation, acting a role, role taking teachers and simultaneous improvisations techniques are used as creative drama techniques [43]. Below in Table 1 there is a drama strategy used in the creative drama practice in this research.

\subsection{Participants}

The research participants consisted of 20 students selected from a seventh-grade classroom in an elementary school in a northern country of Turkey. The conditions in selecting the participants were students access to limited laboratory facilities, selection of the majority of students from rural areas, and non-science teachers. A determining factor also was social-economic status of students at this elementary school is similar. The aim was to select 20 students from an elementary school who have learning difficulties at sixth-grade elementary school biology, poor attitudes toward biology learning at the intermediate level, and poor academic grade point averages.

A low socioeconomic school district participated in this study, because meta-analysis research indicates that children from low socioeconomic families are far more likely to benefit from drama instruction than are students from average populations [44].

Table 1. Drama strategies used in the creative drama practice in this research.

\begin{tabular}{cc}
\hline & Preperation (Warming up) \\
\hline Activity one & Body movement or exercise \\
Activity two & Interim evaluation-I \\
Activity three & Game: Where ar you? I'm here! \\
& Game: Thief and police \\
Activity four & Interim evaluation-II \\
& Dual improvisations \\
Enaction & Interim evaluation-III \\
Evaluation & Main Activity \\
\hline
\end{tabular}




\subsection{Data Collection}

In this research data were obtained in four different ways. Students were provided a journal to keep a log of activities. This log exposed students' understanding and difficulties and their emotions and thoughts. Before and after creative drama activity subject evaluation form is administered to determine the changes in students' understanding of the subject matter. In this form, there are five questions. Drawing technique was used to the fourth question. These are; 1) How many blood types are there? 2) Do you know your blood type? 3) What benefit do you have when you know your blood type? 4) Draw a diagram of a cell representing DNA, gene and chromosome and 5) Do you have any idea how police officers make use of biology while investigating criminals at the stage of collecting evidence? Students evaluated the creative drama activity by responding to 19-item an attitude survey at the end of the study. The drama instructor provided classroom observations of student's performance of the creative drama activity after the application.

\subsection{Data Analysis}

Data obtained from journals, selecting students' important sentences and their expressions are presented without being changed at all. The questions included in the subject evaluation form and attitude survey answers were classified as percent. The drama instructors' classroom observations were grouped by combined common answers.

\subsection{Creative Drama Activity Practice}

Students participated in the creative drama activity called "You are Unique in the World" in the school's drama saloon. The applied drama technique is given below in detail with its stages.

\subsubsection{Preparation for the Creative Drama Activity (Warming up)}

Students are provided opportunity to be ready physically and mentally, by teaching them the related concepts of biology. For example; digestive, excretory or circulatory systems. It is provided at the same time that some certain subjects are reminded according to a leader's command while walking at a musical place. For example; human's process of development. After every creative drama activity and study, interim evaluations are made in order to ask for students' views. Based on these views, information is given and discussed to resolve problems.

1) Activity one

The participants wander around freely inside the room while music is being played. This process is led by the drama instructor. The aim of the preceding practice is to provide warm-up and not only to think how to use body parts to express or how to study our body systems to keep our vitality but also to consider human's process of development. Students first attempt to perceptually determine the space and objects around them. That is, students investigate their physical environment through every observable object, listening to different sounds, experiencing different smells, and touching the objects. Students begin thinking about the exterior surface of the body (skin), a protective wall to the human body, which connects to the external world. Through walking, muscles and bones are felt. The source of energy to move is identified with the complexities of the digestive and excretory systems. The function of the respiratory system is experienced by taking deep breaths. The circulatory system is felt by the heart beats through the carotid artery in the neck. The instructor demonstrates the heart beat and explains the transportation of blood through the vessels throughout the body. This explanation involves how the blood is drawn slowly and how the amount of oxygen in the blood decreases making one unable to take a breath.

Students are asked to imagine their babyhood and their growth. Students are reminded about infancy, beginning with a single cell and growth inside the mother's womb until nine months. Much attention is given to the single cell and the differentiation of this cell giving rise to the unique characteristics of a human being. Students are referred to their parents and ancestors and how their genes are transmitted to the offspring giving the unique properties. Students begin their activity by sitting near the closest wall, leaning back, completely relaxed and listening to their inner voice.

2) Interim evaluation-I:

Participants form a circle. The instructor asks students how they feel and the experiences that make them feel a particular way. Feelings and ideas are shared during the warm-up practice. After sharing their feelings, 
students play "Where are you? I am here" and "Thief and Police”, which are appropriate for the main activity [45].

3) Activity two: game: "Where are you? I am here!"

Students hold hands and stand in a circle. Two volunteers are positioned in the center. First volunteer closes her/his eyes and tries to catch second volunteer. Second volunteer tries to run away from her/him with open eyes. While the first volunteer is trying to tag and find the other volunteer with open eyes, he asks "Where are you?" the running volunteer says "I am here!”. It is the surrounding students' responsibility to protect people inside the circle. The game is repeated by changing roles. Participants in the circle take their turn to play the game.

4) Activity three: game: thief and police

A circle is formed, and two volunteers position themselves in the center of the circle. One is a policeman, and the other is a thief, and both close their eyes. The policeman tries to catch the thief. Those in the circle are responsible for the security. The game is repeated by changing the roles.

5) Interim evaluation-II:

Student participants form a circle by holding hands. The instructor asks participants about their feelings and has them describe the situations they have more difficulty. Students' views about their feelings are explored through questions related to similar situations in their daily lives.

6) Activity four: dual improvisations

Students walk into the place with music accompaniment. Is a group created with the closest person at the end of the music? Before the main activity, dual improvisations are performed during the preparation stage because this was students' first drama experience.

Through this method, students form into group A and group B by themselves. The two groups are asked to choose one of the roles. For example; mother and daughter; teacher and student; two friends; a couple in love; boss and her/his employee; doctor and her/his patient; husband and wife; two colleagues; two children; two cats or any other couple roles they like to act rather than the preceding ones. Simultaneously improvisations start with group A members stating to group members B: “I don’t expect this from you.” Then groups are dismantled when they improvise, and each one is observed. Subsequently couples exchange roles and improvisations are repeated.

7) Interim evaluation-III:

Participants form a circle by holding each other's hands. The instructor asks the participants how $t$ they feel and which situations cause more difficulty. During role performances, students are asked which kind of roles they act emerge from situations.

\subsubsection{Enaction}

In the main activity, students need to have an idea about blood types, learn that each person has a different fingerprint and understands how police officers benefit by learning biology and how the biological concepts are applied during criminal investigations to find criminals. By this means, the place and importance of science to society is realized.

1) Main Activity:

Students form into groups by coding one, two, three, and four. Subsequently, the same numbers come together to form groups of five. Each group is told about their roles and students wait until the preparations are completed. The instructor formulates the course of events because the group does not have any previous drama experience. Later on, improvisations are watched. Improvisations are continuous by starting a little earlier part of stories. Some of the improvisations are simultaneously carried out or by forming a story through a series of story lines.

Group one: You are in a family having a member who gets involved in a shady business deal but in the pretext of loving each other. There is a happy discussion at the end of a happy evening when everybody goes to bed. The mysterious person is awakened secretly. At this time, a burglar enters their home and kills one of the householders and a householder in panic calls the police. The family members are in doubt about whether the murderer is from the household or one of the burglars.

Group two: The person is in a robbery criminal organization conducting the given orders. During the last part of work, it was believed that everybody went to sleep because all of the lights were off, and the person committed a housebreaking crime. One of the members of the groups killed one of the occupants of the house unintentionally. The person had to get out of the house without getting rid of evidence. The police arrest the 
while he attempts to run away.

Group three: The person is an inexperienced police who has just begun his duty. The person has worked in other units before (the teacher gets involved to role-play as an instructor). The person arrives on the scene with a new commander, an experienced police officer in this area on the person's first day at the job. The person or the police arrest the burglars at the end of the chase.

Group four: The person is an official working at a criminal laboratory during the night shift. In the meantime, a policeman calls him, and he is invited for a crime scene investigation (the teacher gets involved as an instructor).

The teacher getting involved role-play beginning the third and fourth groups during the animations provide students with knowledge living. The criminal officials collect blood samples from the scene and determine the blood type by using the blood type indication apparatus. The blood types of all family and robbery gang members are determined and matched with the blood samples gathered from the scene. Thus, potential criminals are found out. Subsequent to this activity, fingerprints are taken from the scene and transferred on to slide by means of friction tape and talcum powder. Then the slide is examined using the microscope and matched with the samples previously taken from potential criminals with stamp?

Collected fingerprint samples are provided in Figure 1 below: These fingerprints can be investigated with magnifying glasses. In order to find the guilty person, the identified person with matching fingerprint is separated from potential criminals having corresponding blood type because every person has a different fingerprint.

\subsubsection{Evaluation}

The participants sit down in a circle. The leader asks the group what they have learned during the various activities. In the process, the instructor assimilates the lessons learned from students' experience and integrates scientific explanation. In addition to the study of sciences, students are encouraged to share their ideas pertaining to what have done thus far. Subsequently, students are asked to write down their views by writing a couple of sentences about the activities they had done that today.

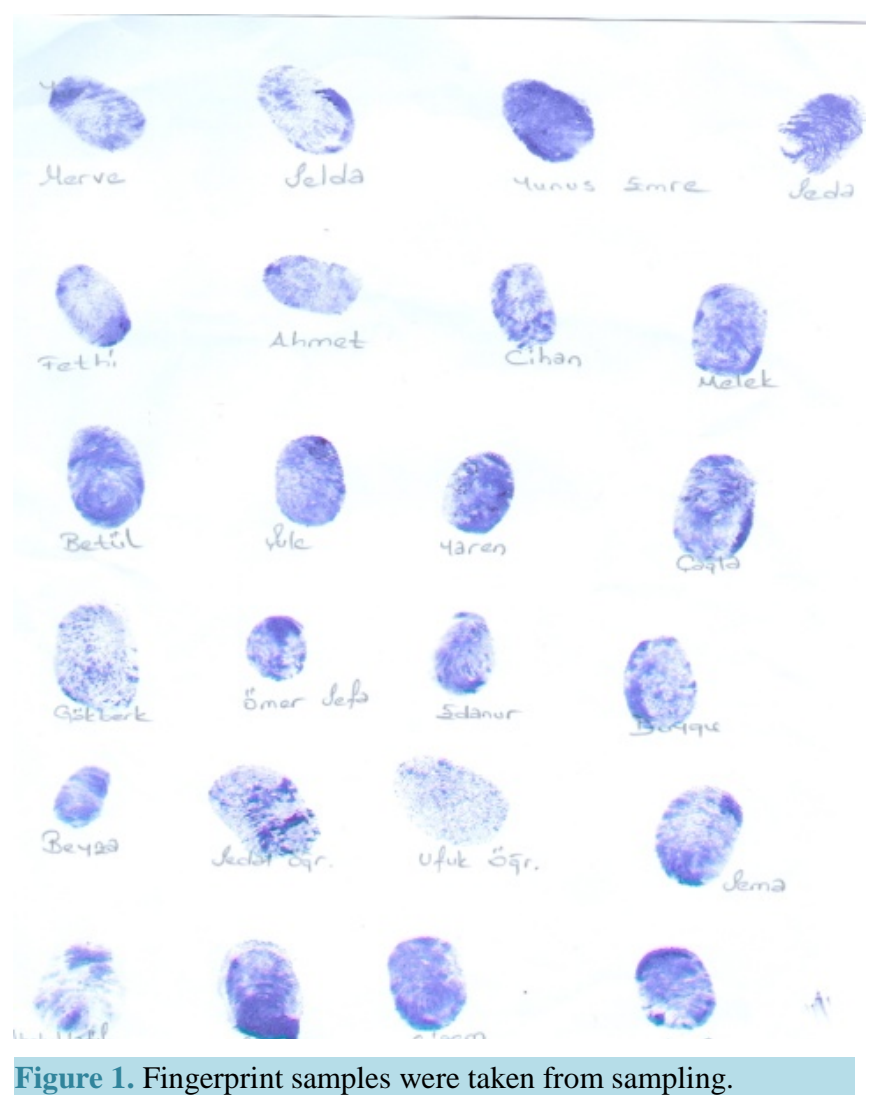




\section{Findings}

In this section, findings are included in the order of students' logs, subject evaluation forms, attitude survey, and instructor observations.

\subsection{Findings from Students' Logs}

Students participating the study are asked to express their ideas written to their logs about conducted creative drama activities. In this section, five students' expressions are presented without being changed at all.

1st student: I have never played drama in my life. I have played it now; it is similar to house games, and I liked it a lot in an inexpressible way...

2nd student: We have acted drama today at drama hall. We have acted as criminal officials and learned a lot of things. We have learned taking blood and a lot more things...

3th student: Later on we have arrived at drama hall. We have had fun and thought about answers to the questions that teacher asked for us while closing our eyes. We have played "Thief and Police" and "where are you, I'm here...

4th student: Attending this kind of a beautiful, enjoyable activity is very beautiful for me...

5th sudent: I have become an ambulance driver at drama today; it have been just an appropriate role for me. I have enjoyed a lot...

\subsection{Finding from Subject Evaluation Forms}

Before and after creative drama activity, a subject evaluation form is administered to determine the changes in students' understanding of the subject matter. Questions are based on blood types. Questions and students' responses are presented in Table 2.

The vertical column in Table 2 clearly indicates students know that there are four kinds of blood types. In addition, 55\% of them have stated that they don't know contraction in scholarly writing knows their blood types. Students have expressed three benefits of knowing blood types: "We help people who are in need of help (65\%)", "It enables us to exchange blood when necessary (25\%)" and "It is necessary for blood transfusion (10\%)". The study confirms that students have learned a variety of blood types and how to determine them. They have stated that they have had opportunity to learn about their blood types.

Since "fingerprint analysis" is also studied within the creative drama, students' level of understanding in this area was also examined. Students' answers to the following question were evaluated. "Draw a diagram of a cell representing DNA, gene and chromosome". Before the creative drama application, 90\% of students responded; "I don't know", $10 \%$ of them were able to draw DNA, gene and chromosome independently. After the creative drama application, $70 \%$ of students drew correct diagrams while $30 \%$ of them drawn diagrams that omitted some parts. Examples of one student's diagrams both before and after the application are represented in Figure 2 and Figure 3.

The percentage of respondents to a question in the subject evaluation form: "All human have DNA, but nobody looks like each other, what might be the reason?" prior to the application are as follows:

"Because all people have different DNA's" (75\%)

"I don’t know” (25\%)

After the application, 75\% students have stated that the difference between human kinds results from different ordering of DNA codes. 20\% of students expressed that it is because of different DNA's and 5\% of them stated that it is because they existed from different ovules. The answers given by students before and after the application for a question from subject evaluation form "Do you have any idea how police officers make use of

Table 2. Questions about blood types and answers given by students before the intervention of creative drama.

\begin{tabular}{|c|c|c|c|}
\hline How many blood types are there? & Do you knov & wn blood & $\begin{array}{l}\text { What benefit do you have when you } \\
\text { know your blood type? }\end{array}$ \\
\hline Correct answer $80 \%$ & Yes (\%) & No (\%) & $\begin{array}{l}\text {-We help people who are in need of help (65\%) } \\
\text {-It enables us to exchange blood when necessary (25\%) }\end{array}$ \\
\hline Wrong answer $20 \%$ & 45 & 55 & -It is necessary for blood transfusion $(10 \%)$ \\
\hline
\end{tabular}




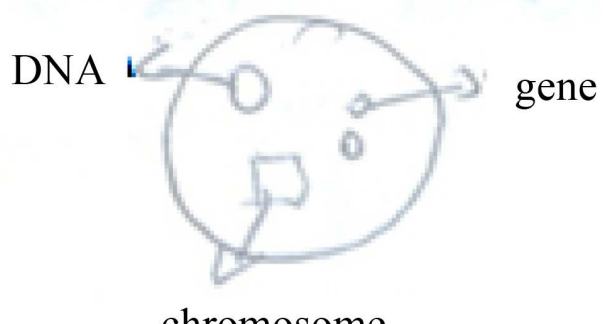

chromosome

Figure 2. Student's diagram before application.

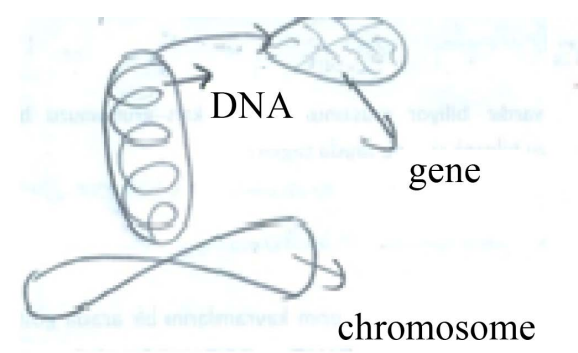

Figure 3. Student's diagram after application.

biology while investigating criminals at the stage of collecting evidence?” are summarized in Table 3 . Thay can choose more than one choice.

Table 3 indicates those students' answers before the application includes correct ideas in different percentages. This shows students have some understanding about the subject. Of these data, 25\% "I don't know" response is interesting. After the application the response to "I don't know" has decreased, and the percentage of other correct answers has increased.

\subsection{Finding from Attitude Survey Forms}

At the end of the intervention, students' attitudes towards biological science are revealed in more detail through an "Attitude Survey" comprised of 19 items. The results obtained from the survey are presented in Table 4.

Evidence in Table 4 reveals that creative drama has increased students' attitudes toward e the learning of biology. Students enjoyed participating in activities. Students' trust towards science and technology increased. Students understood the underlying concepts for most events. Thinking through the questions in various activities encouraged students to think and and respond. They learned better because they were actively engaged in learning. In addition, students' attitudes towards group learning were positively affected. As a result of the intervention, students believed that their self-confidence increased. Students wanted biology topics taught in alternative ways. By looking at these results, we can confidently state that students' attitudes toward biological science are in a positive direction. The results also revealed that students' scientific thinking and social skills have improved. In this context, it is clear that students have had very meaningful experiences with respect to the understanding of the nature of science.

\subsection{Findings from Researcher's Observation}

In order to reveal the level of student's attendance to activities and group discussions, unstructured observations were made by instructors including one creative drama instructor in the process of creative drama activity. These observations were submitted in written at the end of the application. By this way, changes in the students' social skills such as feeling self-confidence, getting in contact with friends were tried to be assessed.

Assessments by the researchers indicate that students participate in activities fondly, they learn while having fun, behave quite compatible with group work, and thus the intended level of success was inferred from the resulting products. Assessments also emphasis that abstained students increase their self-confidence with creative drama exercises towards the end of the project. Students especially using their psychomotor skills to 
Table 3. The responses were given by students before and after the application.

\begin{tabular}{ccc}
\hline Students' answers & Before application \% & After application \% \\
\hline From fingerprints & 55 & 95 \\
From DNA sample & 10 & 5 \\
From gunpowder sample in her/his hands & 5 & 55 \\
From blood & 30 & 10 \\
From salivary and sperm & 5 & 10 \\
From hair & 5 & 5 \\
I don't know & 25 & 5 \\
\hline
\end{tabular}

Table 4. Attitudes toward creative drama application.

\begin{tabular}{|c|c|c|c|}
\hline Items & Yes \% & $\begin{array}{c}\text { Mid } \\
\text { level \% }\end{array}$ & No $\%$ \\
\hline These activities enabled me to like biology topics more. & 90 & 10 & - \\
\hline I enjoyed the activities we made. & 100 & - & - \\
\hline I will allocate more time for assignments related to biology. & 45 & 45 & 10 \\
\hline My trust towards science and technology has increased. & 95 & 5 & - \\
\hline I understand the underlying concepts of most events. More thanks to the knowledge I learned. & 90 & 10 & - \\
\hline The questions asked during the activities did not make me more curious. & 5 & 10 & 85 \\
\hline The activities I constructed enabled me to learn the subject better. & 100 & - & - \\
\hline I could not learn well because we worked in groups. & 15 & 25 & 60 \\
\hline My self-confidence has increased. & 80 & 20 & - \\
\hline We started studying better with my team-mates. & 80 & 10 & 10 \\
\hline I did not experience any change in my self-confidence. & 5 & 10 & 85 \\
\hline My trust towards science and technology has decreased. & - & 5 & 95 \\
\hline I did not understand science based on the activities we developed. & 5 & 10 & 85 \\
\hline We had better communication with our instructors. & 90 & 10 & - \\
\hline I found the activities to be boring. & - & - & 100 \\
\hline The questions asked during the activities made me think more. & 75 & 25 & - \\
\hline The activities we did were not much different from the ones done in our schools. & 5 & 20 & 75 \\
\hline I liked the evaluations of the topics we participated. & 95 & 5 & - \\
\hline I want all biology topics to be taught with these kinds of activities. & 90 & 10 & - \\
\hline
\end{tabular}

generate new products, thought to have changed their perspectives in science.

\section{Discussion and Results}

Considering drama activities in the terms of scientific and creative thinking skills, main tasks and scope of the subject are given to students but the details are let their creative intelligence during the activity. Thus, it has been implemented to express the situation improvisational instead of speech texts. Their impressive performances have drawn attention at the end of the activity. Acquisition of scientific knowledge is provided in the fields of fingerprint and blood type determination.

In the logs of all the students, it has been reported positive opinion about the conducted creative drama activity. Particular emphasis on the feelings and thoughts concentrates on those; they had learned a lot about what they haven't known before, had so much fun, done the works with enthusiasm, spent very nice day and felt 
sad close to the end. In addition, it has been observed that students are aware of the main element of the drama “make pretend” concept. Despite being very shy during animations of the warm up studies, in other studies with the group support and strength they have seen to become more effective in their animations because of the increased self-confidence. In the attitude survey in which students increased their self-confidence had been manifested in their statements from logs and results of observations of the researchers. These results show that students’ self-confidence increases when drama studies have been well established.

According to the logs, instructor's observations and the results of attitude survey; it has seen positive changes in student attitudes towards biology's topics after creative drama application. When the drama studies are performed in a suitable environment and participants are well-organized, it has shown that participants attitude have changed in a positive way towards intended topics and scientific studies.

During the main activity, students have learned new information from their activities and other groups' activities as well. Also, it has been provided to students to learn new information and be aware of what they have learned during evaluation studies and interim evaluations. Moreover, the subject permanency has been obtained by repeats of different students and leader in evaluation studies. For these reasons, in drama studies, it has been taught that performing evaluation stages in effective way increases the efficiency of the studies. Another attainment of evaluation stages in students' favor is that they have the opportunity to evaluate their friends and own performances. In the current science and technology education programs, the emphasis has been put to alternative testing and evaluation in accordance with the constructivist approach. Thanks to such kind of drama studies, students have enabled to make self and peer reviews.

When we consider in terms of pedagogy, we can say: the context of drama lessons may help students to explore some social, genetic issues by ways of democratic teaching. Democratic teaching climate present to students some opportunities: participation some decisions, freely thinking, indication own personal views, discuss various perspective, experience positive class climate, participation in teaching by actively [46]. For example during the creative drama application, all of them are very actively, because each has separate tasks. When the main activity application, different groups looking at events in their terms and they express their views. Finally, they participate some decisions. Because the creative drama application is improvisation, they were having the chance to thinking freely. It is understood from the findings clearly; all participants satisfied from creative drama application, so they have experienced positive classroom atmosphere.

When the results of the study are considered, it is suggested that more creative drama activities should be done in appropriate environments about the topics that students have a learning difficulty. Besides, it is necessary that future studies should be carried out with a leader who has both proficiencies on scientific areas and receives education on the subject of creative drama. When the opinions of study participant students about creative drama are considered, more students should be included into drama experiences, and appropriate opportunities should be created for their participation to these studies at earlier ages actively.

\section{References}

[1] San, I. (1996) An Approach to Enhancing Creativity and a Discipline of Crative İndividuals Educates: Educational Creative Drama. New Turkey Journal, 2, 148-160.

[2] Annarella, L.A. (1999) Using Creative Drama in the Writing Process. ERIC Document Reproduction Service No. ED 402637, Office of Educational Research Improvement, Washington DC.

[3] Duatepe, A. and Akkuş, O. (2006) Use of Creative Drama in Mathematics Education: An Application in Sets Sub Teaching Area. Creative Drama Journal, 1, 89-97.

[4] Paksu, A.D. and Ubuz, B. (2007) Teacher Views about Creative Drama Based Mathematics Lessons. Creative Drama Journal, 1, 193-205.

[5] Du Pont, S. (2009) Raising Comprehension Scores through Creative Drama: Action Research in a Professional Development Partnership. The International Journal of Learning, 16, 291-302.

[6] Adigüzel, H.O. (2002) We Make Dreams Real by Creative Drama! Creative Drama 1985-1995 Writing 1. Naturel Press, Ankara.

[7] Kırmızı, F.S. (2009) Impact on Attitudes for Writing in Turkish Lesson Reative Writing Studies Based on Creative Drama Approach. Creative Drama Journal, 4, 51-65.

[8] Heinig, R.B. (1993) Creative Drama for the Classroom Teacher. Prentice-Hall, Englewood Cliffs.

[9] Somers, J. (1994) Drama in the Curriculum. Cassell, London. 
[10] Lin, Y. (2010) Drama and Possibility Thinking-Taiwanese Pupils’ Perspectives Regarding Creative Pedagogy in Drama. Thinking Skills and Creativity, 5, 108-119. http://dx.doi.org/10.1016/j.tsc.2010.09.001

[11] Dickinson, R. and Neelands, J. (2006) Improve Your Primary School through Drama. David Fulton, London.

[12] Davis, S. and Tarrant, M. (2014) Environmentalism, Stories and Science: Exploring Applied Theatre Processes for Sustainability Education. Research in Drama Education: The Journal of Applied Theatre and Performance, 19, 190194. http://dx.doi.org/10.1080/13569783.2014.895613

[13] Adıgüzel, O., Üstündağ, T. and Öztürk, A. (2007) Drama in Primary School. Anadolu University Press, Eskisehir.

[14] ADC (Arts Development Council) (2005).

[15] AESCDI (Arts Education Section of Curriculum Development Institute) (2005).

[16] Akkuş, O. and Özdemir, P. (2006) A New Look by Creative Drama for Scientists’ Biography and Contrubition to Science. Creative Drama Journal, 1, 59-73.

[17] Baker, B.R. (1996) Drama and Young Children (ERIC Document Reproduction Service No. ED 402637).

[18] Duatepe, A. (2004) The Effect of Drama Based İnstruction on Seventh Grade Students' Geometric Thinking Levels, Attitude toward Mathematics and Geometry. Unpublished Ph.D. Dissertation, Middle East Technical University.

[19] O’Hara, M. (2001) Drama in Education: A Curriculum Dilemma. Theory into Practice, 13, 4.

[20] Boujaoude, S., Sowwan S. and Abd-El-Khalick, F. (2005) The Effect of Using Drama in Science Teaching on Students' Conceptions of Nature of Science. Proceedings of the ESERA Conference, Dordrecht. http://dx.doi.org/10.1007/1-4020-3673-6_21

[21] McNaughton, M.J. (2006) Learning from Participants’ Responses in Educational Drama in the Teaching of Education for Sustainable Development. Research in Drama Education: The Journal of Applied Theatre and Performance, 11, 19-41. http://dx.doi.org/10.1080/13569780500437572

[22] Dalrymple, L. (2006) Has İt Made a Difference? Understanding and Measuring the İmpact of Applied Theatre with Young People in the South African Context. Research in Drama Education: The Journal of Applied Theatre and Performance, 11, 201-218. http://dx.doi.org/10.1080/13569780600671070

[23] Dawson, E., Hill, A., Barlow, J. and Weitkamp, E. (2009) Genetic Testing in a Drama and Discussion Workshop: Exploring Knowledge Construction. Research in Drama Education: The Journal of Applied Theatre and Performance, 14, 361-390. http://dx.doi.org/10.1080/13569780903072174

[24] Marbach-Ad, G. (2001) Attempting to Break the Code in Student Comprehension of Genetic Concepts. Journal of Biological Education, 35, 183-189. http://dx.doi.org/10.1080/00219266.2001.9655775

[25] Collette, A.T. and Chropette, E.L. (1989) Directions and Goals of Science Teaching, Science Instruction in the Middle and Secondary Schools. Science Edition, Merrill Publishing Company, Princeton.

[26] Hurd DeHard, P. (1998) Scientific Literacy: New Minds for a Changing World. Science Education, 82, 407-416. http://dx.doi.org/10.1002/(SICI)1098-237X(199806)82:3<407::AID-SCE6>3.3.CO;2-Q

[27] Bahar, M., Johnstone, A.H. and Hansell, M.H. (1999) Revisiting Learning Difficulties in Biology. Journal of Biological Education, 33, 84-86. http://dx.doi.org/10.1080/00219266.1999.9655648

[28] Bahar, M., Johnstone, A.H. and Sutcliffe, R.G. (1999) Investigation of Students' Cognitive Structure in Elementary Genetics through Word Association Tests. Journal of Biological Education, 33, 134-142. http://dx.doi.org/10.1080/00219266.1999.9655653

[29] Bahar, M. (2002) Students' Learning Difficulties in Biology: Reasons and Solutions. Journal of Kastamonu Faculty of Education, 10, 73-82.

[30] Kinfield, C.A. (1994) Understanding a Basic Biological Process: Expert and Novice Models of Meiosis. Science Education, 78, 255-283. http://dx.doi.org/10.1002/sce.3730780308

[31] Tekkaya, C., Capa, Y. and Y1lmaz, O. (2000) Teacher Candidates’ Misconceptions about Biology Topics. Journal of Hacettepe University Faculty of Education, 18, 140-147.

[32] Tekkaya, C., Özkan, O. and Sungur, S. (2001) Biology Concepts Perceived as Difficult by Turkish High School Students. Journal of Hacettepe University Faculty of Education, 21, 145-150.

[33] Tsui, C. and Treagust, D.F. (2003) Genetics Reasoning with Multiple External Representations. Research in Science Education, 33, 111-135. http://dx.doi.org/10.1023/A:1023685706290

[34] Ramorago, G. and Wood-Robinson, C. (1995) Batswana Children's Understanding of Biological İnheritance. Journal of Biological Education, 29, 60-72. http://dx.doi.org/10.1080/00219266.1995.9655420

[35] Johnstone, A.H. and Mahmoud, N.A. (1980) Isolating Topics of High Perceived Difficulty in School Biology. Journal of Biological Education, 14, 164-166. http://dx.doi.org/10.1080/00219266.1980.10668983 
[36] Saka, A. and Akdeniz, A.R. (2004) Variation of Concepts in Relation to the Genetic Subjects at Different Student Levels. Journal of Sakarya University Faculty of Education, 7, 188-209.

[37] Saka, A., Cerrah, L., Akdeniz, A.R. and Ayas, A. (2006) A Cross-Age Study of the Understanding Three Genetic Concepts: How Do They İmage the Gene, DNA and Chromosome? Journal of Science Education and Technology, 15, 192-202. http://dx.doi.org/10.1007/s10956-006-9006-6

[38] Deboer, E.G. (1991) A History of İdeas in Science Education: İmplication for Practice. Teacher Collage Press, New York.

[39] Öztaş, H. and Öztaş, F. (1998) Research on Different Level Students’ Ability to Comprehend Some Basic Biology Concept. III National Science Education Symposium, Trabzon, 23-25 September 1998, 184-187.

[40] Saka, A. and Cerrah, L. (2004) Evaluation of Science Student Teachers’ Views about Genetic Concepts. Journal of Çukurova University Faculty of Education, 2, 46-51.

[41] Sahin F. and Parim, G. (2002) Teaching for DNA, Gene and Chromosome Concepts with Problem Based Teaching Method. V National Science and Mathematics Education Congress, Ankara, 16-18 September 2002.

[42] Çepni, S., Ayas, A., Ekiz, D. and Akyıldız, S. (2008) Principles and Methods in Education. Celepler Press, Trabzon.

[43] Adıgüzel, H.O. (2012) Creative Drama in Education. Second Edition, Naturel Press, Ankara.

[44] Podlozny, A. (2000) Strengthening Verbal Skills through the Use of Classroom Drama: A Clear Link. Journal of Aesthetic Education, 34, 239-276. http://dx.doi.org/10.2307/3333644

[45] Ataman, M. and Erem, E. (2007) Modern Drama Society Leadership/Instructiveness Programme Basic Stage Workshop Notes.

[46] McNaughton, M.J. (2010) Educational Drama in Education for Sustainable Development: Ecopedagogy in Action. Pedagogy, Culture and Society, 18, 289-308. http://dx.doi.org/10.1080/14681366.2010.505460 